\title{
ANTIOXIDANT, ANTI-INFLAMMATORY AND HEPATOPROTECTIVE ACTIVITIES ON CARBON TETRACHLORIDE - INDUCED HEPATIC DAMAGE IN MICE OF Ixora duffii LEAF EXTRACT
}

\author{
Phan Kim Dinh, Nguyen Trong Tuan, Dai Thi Xuan Trang* \\ College of Natural Sciences, Can Tho University \\ Received 9 July 2018, accepted 11 February 2019
}

\begin{abstract}
The in vitro total antioxidant and anti-inflammatory capacity of the methanol extract of Ixora duffii leaf ("Trang to" in Vietnamese) was investigated using the phosphomolypdenum method and the bovine serum albumin denaturation test, respectively. The results showed that the methanol extract of $I$. duffii leaf possessed relatively high antioxidant activity $\left(\mathrm{OD}_{0,5}=15.551 \pm\right.$ $0.344 \mu \mathrm{g} / \mathrm{mL})$ compared to that of the standard, trolox $\left(\mathrm{OD}_{0,5}=2.315 \pm 0.083 \mu \mathrm{g} / \mathrm{mL}\right)$. The antiinflammatory effect using bovine serum albumin denaturation test showed that the activity of the methanol extract of $I$. duffii leaf $\left(\mathrm{EC}_{50}=6.03 \pm 0.12 \mu \mathrm{g} / \mathrm{mL}\right)$ was comparable to that of the reference drug, diclofenac sodium $\left(\mathrm{EC}_{50}=0.57 \pm 0.21 \mu \mathrm{g} / \mathrm{mL}\right)$. To evaluate the hepatoprotective activity of the methanol extract of $I$. duffii leaf, the liver damage was induced in mice given with carbon tetrachloride $\left(\mathrm{CCl}_{4}\right)$ mixed in olive oil (1:4) at a dose of $2.5 \mathrm{~mL} / \mathrm{kg}$ body weight/day. As a control, the standard hepatoprotective agent, silymarin, was used at the dose of $16 \mathrm{mg} / \mathrm{kg}$ body weight for 4 consecutive weeks. I. duffii leaf extract was given at three different doses 100, 200 and $400 \mathrm{mg} / \mathrm{kg}$ body weight. The results showed the effective dose-dependent reduction of transaminase enzyme (ALT and AST) levels in sera. In addition, I. duffii leaf extract also improved the oxidative stress status of the liver through effective reduction of MDA level and increase of GSH level in the liver. Histopathological examination of the liver tissue revealed that the mice treated with $I$. duffii leaf extract showed significant improvement of liver tissue damages similar to silymarin treatment compared to the non-treated control group. The present results demonstrated that $I$. duffii leaf extract has potent antioxidant and hepatoprotective activity.
\end{abstract}

Keywords: Ixora duffii, antioxidant, anti-inflammatory, ALT, AST, carbon tetrachloride $\left(\mathrm{CCl}_{4}\right)$, GSH, MDA, hepatoprotective activity.

Citation: Phan Kim Dinh, Nguyen Trong Tuan, Dai Thi Xuan Trang, 2019. Antioxidant, anti-inflammatory and hepatoprotective activities on carbon tetrachloride - induced hepatic damage in mice of Ixora duffii. leaf extract. Tap chi Sinh hoc, 41(1): 117-128. https://doi.org/10.15625/0866-7160/v41n1.12734.

*Corresponding author email: dtxtrang@ctu.edu.vn

(O2019 Vietnam Academy of Science and Technology (VAST) 


\title{
KHẢO SÁT HOẠT TÍNH CHỐNG OXY HÓA, CHỐNG VIÊM VÀ HOẠT TÍNH BẢO VÊ GAN TRÊN CHUỘT TỔN THƯƠNG GAN BẦNG CARBON TETRACHLORIDE CỦA CAO CHIẾT LÁ TRANG TO (Ixora duffii)
}

\author{
Phan Kim Định, Nguyễn Trọng Tuân, Đái Thị Xuân Trang* \\ Khoa Khoa học Tự nhiên, Đại học Cần Thơ \\ Ngày nhận bài 9-7-2018, ngày chấp nhận 11-2-2019
}

\section{TÓM TẮT}

Cây Trang to (Ixora duffii) thuộc chi Ixora họ Rubiaceae. Hoạt tính chống oxy hóa và chống viêm in vitro của cao methanol lá $I$. duffii được khảo sát bằng phương pháp phosphomolybdenum và phương pháp ức chế sự biến tính albumin huyết thanh bò. Kết quả cho thấy, cao methanol lá $I$. duffii có khả năng chống oxy $\left(\mathrm{OD}_{0,5}=15,551 \pm 0,344 \mu \mathrm{g} / \mathrm{mL}\right)$ thấp hơn trolox $\left(\mathrm{OD}_{0,5}=2,315 \pm\right.$ $0,083 \mu \mathrm{g} / \mathrm{mL}$ ) dùng trong thử nghiệm 6,7 lần. Hiệu quả kháng viêm dựa trên khả năng ức chế sự biến tính protein của lá $\left(\mathrm{EC}_{50}=5,57 \pm 0,12 \mu \mathrm{g} / \mathrm{mL}\right)$ thấp hơn diclofenac $\left(\mathrm{EC}_{50}=0,57 \pm\right.$ $0,21 \mu \mathrm{g} / \mathrm{mL}$ ) là 9,77 lần. Hoạt động bảo vệ gan của cao lá $I$. duffii được khảo sát trên chuột tổn thương gan bằng carbon tetrachloride $\left(\mathrm{CCl}_{4}\right)$ pha trong dầu olive (tỉ lệ $\left.1: 4\right)$ liều $2,5 \mathrm{~mL} / \mathrm{kg}$ khối lượng/lần/ngày bằng đường uống. Thuốc bảo vệ gan silymarin liều $16 \mathrm{mg} / \mathrm{kg}$ khối lượng/ lần/ ngày được sử dụng như chất đối chứng dương. Chuột tổn thương gan được điều trị bằng cách cho uống cao chiết lá Trang to hoặc thuốc silymarin sau một giờ uống $\mathrm{CCl}_{4}$, thí nghiệm được thực hiện liên tục 4 tuần. Kết quả ở các liều khảo sát cao methanol lá $I$. duffii 100,200 và $400 \mathrm{mg} / \mathrm{kg}$ khối lượng chuột đều cho hiệu quả làm giảm hàm lượng enzyme transaminase trong huyết thanh rất tốt, với hàm lượng $\operatorname{ALT}(104,80 \pm 14,84 \mathrm{U} / \mathrm{L}, 84,20 \pm 20,02 \mathrm{U} / \mathrm{L}, 45,00 \pm 21,06 \mathrm{U} / \mathrm{L})$ và $\mathrm{AST}$ $(137,40 \pm 26,30 \mathrm{U} / \mathrm{L}, 119,20 \pm 6,40 \mathrm{U} / \mathrm{L}$ và $88,80 \pm 14,62 \mathrm{U} / \mathrm{L})$ lần lượt ở các nồng độ khảo sát tăng dần. Bên cạnh đó, cao lá còn cải thiện được trạng thái stress oxy hóa trong gan qua hiệu quả làm giảm mức $\mathrm{MDA}$ và làm tăng mức GSH trong mô gan tương tự silymarin. Quan sát tiêu bản hiển vi lát cắt ngang gan chuột cũng cho thấy cấu trúc mô gan được cải thiện so với nhóm đối chứng bệnh lý và tương đương với silymarin liều $16 \mathrm{mg} / \mathrm{kg}$ khối lượng chuột. Kết quả chứng minh được hiệu quả của loại cao này trong hoạt động chống oxy hóa và bảo vệ gan.

Từ khóa: Ixora duffii, enzyme ALT, enzyme AST, MDA, GSH, chống oxy hóa, chống viêm, tetrachloric carbon $\left(\mathrm{CCl}_{4}\right)$.

*Địa chỉ liên hệ email: dtxtrang@ @ctu.edu.vn

\section{MỞ ĐẦU}

Gan đóng vai trò quan trọng trong sự cân bằng trao đổi chất của cơ thể vì gan là cơ quan chính chịu trách nhiệm về sự trao đổi chất, tổng hợp, lưu trữ và phân phối lại các carbohydrate, các vitamin và chất béo. Vì vậy, gan là nơi có hoạt động trao đổi chất cao và là nơi quan trọng sinh ra các gốc tự do (Arauz et al., 2016). Việc sinh ra các gốc tự do quá mức gây stress oxy hóa trong cơ thể bởi chúng gây ra các tác động có hại cho cấu trúc tế bào. Bên cạnh đó, sự tiếp xúc liên tục của gan với một số yếu tố như virus, rượu, các chất độc hại, chất béo, các chất chuyển hóa sinh học... cũng gây stress oxy hóa trong gan có thể dẫn đến viêm và thoái hóa gan. Tổn thương gan kéo dài có thể gây ra các bệnh về gan mãn tính (Chatterjee \& Mitra, 2015; Li et al., 2015). Stress oxy hóa trên gan ảnh hưởng đến các 
chất chống oxy hóa như superoxide dismutase (SOD), catalase (CAT), glutathione reductase (GSH) và tăng sự peroxide hóa lipid (LPO) trong gan (Banu et al., 2012; Habib et al., 2015). Sử dụng chất chống oxy hoá ngoại sinh là một cách hợp lý để phòng ngừa và điều trị các bệnh về gan có liên quan đến stress oxy hóa (Medina et al., 2005). Chất chống oxy hóa tự nhiên chứa trong các thực vật làm thức ăn hoặc làm thuốc thường có khả năng chống oxy hóa và làm sạch gốc tự do mạnh cũng như tác dụng chống viêm được coi là cơ sở của các hoạt tính sinh học có lợi cho sức khỏe (Li et al., 2015). Việc nghiên cứu phát hiện các loài thực vật có khả năng chống oxy hóa, chống viêm và bảo vệ gan được coi là cơ sở của các nghiên cứu tìm ra phương pháp điều trị các bệnh về gan một cách an toàn và hiệu quả.

Trên thế giới đã có nhiều nghiên cứu về khả năng chống oxy hóa và bảo vệ gan của các loại thực vật khác nhau, đặc biệt, một số loài trong chi Ixora (Rubiaceae) đã được chứng minh có hoạt tính chống oxy hóa, chống viêm và bảo vệ gan (Dontha et al., 2015). Ở Việt Nam, cây Trang to, Ixora duffii, mọc hoang hoặc được trồng ở nhiều nơi vì phát hoa to, thường dùng để cúng (Phạm Hoàng Hộ, 2003), kinh nghiệm chữa bệnh chưa được phổ biến. Mục tiêu của nghiên cứu này là khảo sát khả năng chống oxy hóa, chống viêm và bảo vệ gan của cao chiết lá Ixora duffii.

\section{VÂT LIỆU VÀ PHƯƠNG PHÁP NGHIÊN CứU}

Thiết bị được sử dụng trong nghiên cứu bao gồm máy cô quay chân không (Heidolph, Đức), máy đo quang phổ (BecKman Coulter 640B, USA), kính hiển vi quang học (Olympus, Nhật Bản), máy cắt mầu (RM2125RT, Leica, Đức) và các thiết bị khác.

Hóa chất sử dụng trong thí nghiệm gồm albumin huyết thanh bò (BSA) (Himedia), silymarin (Sigma-Aldrich), methanol (Trung Quốc), glutathione (Đài Loan), hematoxylin (Merck), eosin Y (BDH, Anh), $\mathrm{CCl}_{4}$ (Merck) và một số hóa chất khác.

Vật liệu thí nghiệm là cao methanol chiết từ lá loài Ixora duffii được thu hái tại Vĩnh
Long, được định danh dựa vào hình thái cơ quan thực vật theo Phạm Hoàng Hộ (2003).

Đối tượng thí nghiệm là chuột nhắt trắng (Mus musculus var Albino) khỏe mạnh, trọng lượng từ 20-25 gram do Viện Pasteur, thành phố Hồ Chí Minh cung cấp, được nuôi ở phòng thí nghiệm Bộ môn Sinh học, Khoa Khoa học Tự nhiên, Trường Đại Học Cần Thơ ở nhiệt độ phòng và chu kỳ sáng tối 12/12 giờ.

\section{Khảo sát hàm lượng chất chống oxy hóa của cao chiết lá $I$. duffii}

Khả năng chống oxy hoá của cao chiết được đánh giá bằng phương pháp phosphomolybdenum theo Prieto et al. (1999). Phương pháp này dùng đánh giá cả chất chống oxy hóa hòa tan trong nước và chất chống oxy hóa hòa tan trong dầu (còn gọi là khả năng chống oxy hóa tổng) (Aliyu et al., 2013). Hỗn hợp phản ứng gồm $0,3 \mathrm{~mL}$ cao chiết kết hợp với $3 \mathrm{~mL}$ dung dịch thử $(0,6 \mathrm{M}$ acid sulfuric, $28 \mathrm{mM}$ sodium phosphate và $4 \mathrm{mM}$ ammonium molybdate). Các ống chứa dung dịch phản ứng được ủ ở $95^{\circ} \mathrm{C}$ trong 90 phút. Sau khi ủ, hỗn hợp phản ứng được làm mát ở nhiệt độ phòng, đo độ hấp thụ quang phổ ở bước sóng $695 \mathrm{~nm}$. Methanol $(0,3 \mathrm{~mL})$ thay cho cao chiết được sử dụng làm đối chứng âm. Khả năng chống oxy hoá của lá thể hiện bằng hàm lượng chất chống oxy hóa tương đương $\mu \mathrm{g} / \mathrm{mL}$ trolox.

\section{Khảo sát hoạt tính chống viêm in vitro của cao chiết lá $I$. duffii}

Khả năng chống viêm của cao chiết lá được khảo sát thông qua hoạt động ức chế sự biến tính protein được thực hiện theo phương pháp của Shah et al. (2017) có hiệu chỉnh. Dung dịch thử $1 \mathrm{~mL}$ (ở các nồng độ: 6,25 , $12,5,25,50$ và $100 \mu \mathrm{g} / \mathrm{mL}$ ) được trộn với 1 $\mathrm{ml}$ dung dịch BSA 5\%. Sau đó, hỗn hợp được ủ ở $27^{\circ} \mathrm{C}$ trong 15 phút. Sự biến tính protein được tạo ra bằng cách giữ hỗn hợp phản ứng ở $60^{\circ} \mathrm{C}$ trong 10 phút. Sau khi làm mát, tiến hành đo mật độ quang tại bước sóng $660 \mathrm{~nm}$. Thuốc chống viêm diclofenac được sử dụng như chất chông viêm tiêu chuẩn. Khả năng ức chế sự biến tính protein của cao chiết lá Trang to được xác định theo công thức sau: \% Úc chế $=100(1-\mathrm{Vt} / \mathrm{Vc})$. Trong đó, Vt: Mật độ 
quang của mẫu thử, $\mathrm{Vc}$ : Mật độ quang của mẫu đối chứng không có cao chiết.

\section{Khảo sát hoạt tính bảo vệ gan của cao chiết lá I. duffii}

Thí nghiệm khảo sát hoạt tính bảo vệ gan của cao methanol lá được tiến hành theo phương pháp của Kang \& Koppula (2014) có hiệu chỉnh. Chuột được gây tôn thương gan bằng carbon tetrachloride $\left(\mathrm{CCl}_{4}\right)$ liều 2,5 $\mathrm{mL} / \mathrm{kg}$ khối lượng chuột $\left(\mathrm{CCl}_{4}\right.$ pha trong dầu olive theo tỉ lệ 1:4). Chuột sau tôn thương gan được điều trị bằng cao chiết methanol lá Trang to liều 100, 200 hoặc $400 \mathrm{mg} / \mathrm{kg}$ khối lượng; tinh chất silymarin liều $16 \mathrm{mg} / \mathrm{kg}$ được sử dụng như thuốc bảo vệ gan đối chứng. Dimethyl sulfoxide (DMSO) 1\% được dùng pha cao chiết và silymarin. Sau 1 giờ chuột uống $\mathrm{CCl}_{4}$ được uống cao methanol lá hoặc silymarin với liều tương ứng liều điều trị mô tả ở trên/ lần $\times 1$ lần/ngày.

Chuột đực và cái khỏe mạnh được chia ngẫu nhiên thành 7 công thức thí nghiệm, mỗi công thức gồm 6 con chuột. Các công thức chuột thí nghiệm được bố trí như sau: công thức đối chứng sinh lý (chuột bình thường uống nước cất); công thức chuột uống DMSO 1\%; công thức đối chứng bệnh lý (chuột chỉ uống $\mathrm{CCl}_{4}$ ); công thức đối chứng dương (chuột tổn thương gan điều trị bằng silymarin liều $16 \mathrm{mg} / \mathrm{kg}$ khối lượng); các công thức chuột tổn thương gan điều trị bằng cao chiết lá liều $100 \mathrm{mg} / \mathrm{kg}$ hoặc $200 \mathrm{mg} / \mathrm{kg}$ hoặc 400 mg/kg khối lượng.

Thời gian thí nghiệm kéo dài 4 tuần, kết thúc thí nghiệm chuột được cân khối lượng, gây mê giải phẫu lấy máu ở tim xét nghiệm sinh hóa, gan được tách lấy rửa qua dung dịch sinh lý và chia làm hai phần, một phần để phân tích sinh hóa và phần còn lại để thực hiện tiêu bản mô học.

\section{Đánh giá sinh hóa}

Khả năng bảo vệ gan được đánh giá bằng việc xác định hoạt độ của enzyme ALT, AST trong huyết thanh và hàm lượng $\mathrm{MDA}$ và GSH trong gan. Máu chuột thí nghiệm được đo hoạt độ enzyme ALT và AST bằng máy xét nghiệm sinh hóa bán tự động Erba CHEM - 7. Đồng thời gan chuột được xử lý và tiến hành định lượng malondialdehyd (MDA) và glutathione (GSH) theo phương pháp của Ohkawa et al. (1979) và Moron et al. (1979) được hiệu chỉnh theo Nguyễn Bảo Trân và nnk. (2011). Gan chuột được tách ra khỏi cơ thể và nghiền đồng thể trong dung dịch đệm $\mathrm{KCl} 1,15 \%$ ở nhiệt độ $4^{\circ} \mathrm{C}$. Dịch đồng thể gan gồm $1 \mathrm{~mL}$ được trộn với $0,5 \mathrm{~mL}$ dung dịch đệm phosphate $25 \mathrm{mM}$ $(\mathrm{pH}=7,4)$ và ủ ở $37^{\circ} \mathrm{C}$ trong 60 phút. Phản ứng sau khi được kết thúc bằng $0,5 \mathrm{~mL}$ acid tricloacetic $10 \%$ được ly tâm 13.000 vòng/phút trong 10 phút ở $4^{\circ} \mathrm{C}$. Phần dịch lỏng sau khi ly tâm được sử dụng để xác định hàm lượng $\mathrm{MDA}$ và $\mathrm{GSH}$.

Hàm lượng malondialdehyde (MDA) được xác định như sau: Lấy $1 \mathrm{~mL}$ dịch ly tâm cho phản ứng với $0,5 \mathrm{~mL}$ thiobarbituric $0,8 \%$ ở $100^{\circ} \mathrm{C}$ trong 30 phút và đo mật độ quang ở bước sóng $532 \mathrm{~nm}$. Hàm lượng MDA $(\mathrm{nM} / \mathrm{g})$ được tính dựa theo phương trình hồi quy tuyến tính của chất chuẩn MDA.

Hàm lượng glutathione (GSH) được xác định như sau: $1 \mathrm{~mL}$ dịch ly tâm được phản ứng với $0,2 \mathrm{~mL}$ thuốc thử Ellman và 1,8 mLdung dịch đệm EDTA phosphate. Hỗn hợp phản ứng được để yên 3 phút ở nhiệt độ phòng và sau đó tiến hành đo mật độ quang ở bước sóng $412 \mathrm{~nm}$. Hàm lượng $\mathrm{GSH}(\mathrm{nM} / \mathrm{g})$ được tính dựa theo phương trình hồi quy tuyến tính của chất chuẩn GSH.

\section{Thực hiện tiêu bản mô bệnh học}

Tách lấy một thùy nhỏ của gan chuột thí nghiệm ngâm trong dung dịch formol $4 \%$ ít nhất 24 giở, xử lý và tiến hành tẩm paraffinxylen, đúc khuôn theo qui trình thực hiện tiêu bản mô học của Saalu et al. (2012) có hiệu chỉnh. Mẫu được cắt bằng máy cắt microtome thành các lát cắt có độ dày khoảng $5 \mu \mathrm{m}$, khử paraffin và nhuộm với hematoxylin và eosin, quan sát dưới kính hiển vi để đánh giá mô học.

\section{Thống kê phân tích số liệu}

Số liệu được trình bày bằng MEAN \pm SEM. Kết quả được xử lý thống kê theo phương pháp ANOVA bằng phần mềm Excel và Minitab 16.0. 


\section{KẾT QUẢ NGHIÊN CƯU}

Hàm lượng chất chống oxy hóa của cao chiết lá $I$. duffii

Khả năng chống oxy hóa của cao chiết lá I. duffii được trình bày trong bảng 1 cho thấy, lá có hàm lượng chất chống oxy hóa tương đương chất chống oxy hóa chuẩn trolox tăng theo nồng độ cao chiết.

Hiệu quả chống oxy hóa của cao methanol lá được so sánh với chất chuẩn trolox bằng cách sử dụng nồng độ mà tại đó chất chuẩn hay cao chiết $(\mu \mathrm{g} / \mathrm{mL})$ có giá trị $\mathrm{OD}=0,5\left(\mathrm{OD}_{0,5}\right)$. Kết quả cho thấy, khả năng chống oxy hóa của lá $I$. duffii $\left(\mathrm{OD}_{0,5}=15,56 \pm 0,34 \mu \mathrm{g} / \mathrm{mL}\right)$ thấp hơn trolox $\left(\mathrm{OD}_{0,5}=2,32 \pm 0,08 \mu \mathrm{g} / \mathrm{mL}\right)$ dùng trong thử nghiệm 6,7 lần.

Bảng 1. Hàm lượng chất chống oxy hóa tương đương $\mu \mathrm{g} / \mathrm{mL}$ trolox của cao chiết lá $I$. duffii

\begin{tabular}{|c|c|}
\hline $\begin{array}{c}\text { Nồng độ } \\
\text { cao chiết } \\
(\mu \mathrm{g} / \mathrm{mL})\end{array}$ & $\begin{array}{c}\text { Hàm lượng chất chống oxy } \\
\text { hóa tương đương } \mu \mathrm{g} / \mathrm{mL} \\
\text { trolox }\end{array}$ \\
\hline 0 & - \\
\hline 10 & $1,48^{\mathrm{j}} \pm 0,03$ \\
\hline 20 & $2,78^{\mathrm{i}} \pm 0,07$ \\
\hline 30 & $3,96^{\mathrm{h}} \pm 0,05$ \\
\hline 40 & $5,44^{\mathrm{g}} \pm 0,15$ \\
\hline 50 & $6,72^{\mathrm{f}} \pm 0,30$ \\
\hline 60 & $7,37^{\mathrm{e}} \pm 0,30$ \\
\hline 70 & $9,25^{\mathrm{d}} \pm 0,03$ \\
\hline 80 & $10,30^{\mathrm{c}} \pm 0,07$ \\
\hline 90 & $10,69^{\mathrm{b}} \pm 0,22$ \\
\hline 100 & $12,02^{\mathrm{a}} \pm 0,18$ \\
\hline
\end{tabular}

Ghi chú: các mẫu tự theo sau các giá trị trong cùng một cột khác nhau thì khác biệt ý nghĩa về mặt thống kê ở mức 5\% ( $p<0,05)$; - không xác định.

\section{Hoạt tính chống viêm in vitro của cao chiết lá I. duffii}

Hoạt tính chống viêm của cao chiết lá được xác định bằng hoạt động chống viêm in vitro thông qua hoạt động ức chế sự biến tính protein albumin huyết thanh bò (BSA) được so sánh với chất chống viêm chuẩn diclofenac thể hiện ở hình 1 .

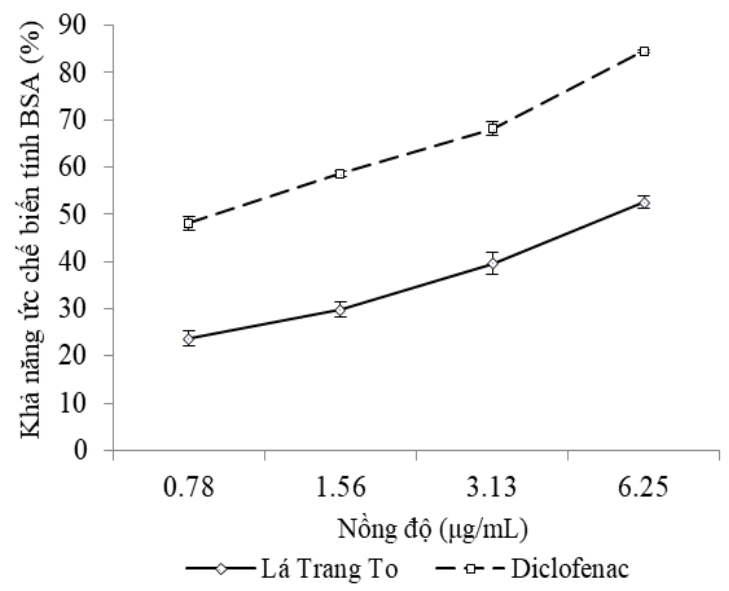

Hình 1. Hiệu quả ức chế sự biến tính protein của cao methanol lá I. duffii

Ngoài ra, khả năng ức chế sự biến tính protein của cao chiết lá Trang to còn được xác định dựa vào giá trị $\mathrm{EC}_{50}$ (effective concentration of $50 \%$ ) để so sánh với chất chuẩn diclofenac. Kết quả cho thấy, hiệu quả ức chế sự biến tính protein cũng như hiệu quả chống viêm của cao chiết lá Trang to $\left(\mathrm{EC}_{50}=\right.$ $5,57 \pm 0,12 \mu \mathrm{g} / \mathrm{mL}$ ) thấp hơn diclofenac $\left(\mathrm{EC}_{50}=0,57 \pm 0,21 \mu \mathrm{g} / \mathrm{mL}\right)$ là 9,77 lần.

\section{Hoạt tính bảo vệ gan của cao chiết lá $I$.} duffii

Hoạt tính bảo vệ gan của cao chiết lá Trang to được khảo sát qua hiệu quả bảo vệ gan trên chuột được gây tổn thương gan bằng $\mathrm{CCl}_{4}$. Hiệu quả bảo vệ gan được đánh giá qua kết quả các chỉ tiêu sinh hóa bao gồm hàm lượng enzyme ALT và AST trong huyết thanh, hàm lượng MDA và GSH trong gan kết hợp với kết quả quan sát hình thái và mô bệnh học gan chuột sau thí nghiệm.

Hàm lượng enzyme aspartate transaminase (AST), alanine aminotransferase (ALT) trong huyết thanh và malondialdehyde (MDA), glutathione (GSH) trong gan chuột

Thông qua việc xác định hàm lượng AST và $A L T$ huyết thanh, $M D A$ và GSH trong gan của chuột thí nghiệm có thể xác định được mức độ tổn thương của gan cũng như khả năng bảo vệ gan của cao chiết lá $I$. duffii. Các giá trị sinh hóa được trình bày trong bảng 2 . Kết quả ở bảng 2 cho thấy hoạt động của các 
enzyme ALT, AST tăng cao ở công thức đối chứng bệnh $\left(\mathrm{CCl}_{4}\right)$ so với các công thức đối chứng sinh lý và DMSO $1 \%(\mathrm{p}<0,05)$, phản ánh sự tổn thương ở mô gan. Hàm lượng enzyme gan ALT và AST ở các công thức chuột điều trị bằng cao chiết lá $(100,200$ hoặc $400 \mathrm{mg} / \mathrm{kg}$ ) và silymarin đã giảm theo hướng về mức bình thường. Hiệu quả làm giảm hoạt độ enzyme phụ thuộc vào liều, ở liều 200 $\mathrm{mg} / \mathrm{kg}$ có thể so sánh với thuốc chuẩn silymarin $(16 \mathrm{mg} / \mathrm{kg})$ và liều $400 \mathrm{mg} / \mathrm{kg}$ có thể đưa hoạt độ enzyme về mức bình thường.

Sự thay đổi hàm lượng MDA và GSH trong gan cũng được trình bày trong bảng 2 .
Kết quả ở bảng 2 cho thấy, công thức chuột đối chứng bệnh có hàm lượng MDA tăng khác biệt có ý nghĩa thống kê trong khi hàm lượng GSH giảm có ý nghĩa thống kê so với công thức đối chứng sinh lý. Sự thay đổi hàm lượng MDA và GSH là do sự stress oxy hóa và peroxide hóa lipid xảy ra mạnh mẽ ở gan. Ở các công thức chuột điều trị bằng cao chiết lá Trang to $(100,200$ hoặc $400 \mathrm{mg} / \mathrm{kg})$ và silymarin đã cải thiện trạng thái stress oxy hóa và peroxide hóa lipid ở gan theo xu hướng làm giảm MDA và làm tăng GSH. Khi điều trị bằng cao chiết lá $I$. duffii ở liều $400 \mathrm{mg} / \mathrm{kg}$, kết quả đạt được tốt hơn silymarin liều $16 \mathrm{mg} / \mathrm{kg}$.

Bảng 2. Hàm lượng ALT, AST, MDA và GSH của chuột sau thí nghiệm

\begin{tabular}{|l|c|c|c|c|}
\hline \multirow{2}{*}{\multicolumn{1}{|c|}{ Công thức }} & \multicolumn{4}{c|}{ Hàm lượng } \\
\cline { 2 - 5 } & ALT (U/L) & AST (U/L) & MDA (nmol/g) & GSH $(\mathrm{nmol} / \mathrm{g})$ \\
\hline Đối chứng sinh lý (nước cất) & $34,4^{\mathrm{b}} \pm 8,90$ & $169^{\mathrm{b}} \pm 12,40$ & $1,95^{\mathrm{d}} \pm 0,23$ & $524,10^{\mathrm{d}} \pm 77,30$ \\
\hline DMSO $1 \%$ & $69,80^{\mathrm{b}} \pm 21,30$ & $178,20^{\mathrm{b}} \pm 43,00$ & $2,01^{\mathrm{d}} \pm 0,20$ & $487,20^{\mathrm{d}} \pm 46,00$ \\
\hline Đối chứng bệnh $\left(\mathrm{CCl}_{4}\right)$ & $921,2^{\mathrm{a}} \pm 375,00$ & $1386,40^{\mathrm{a}} \pm 354,5$ & $16,10^{\mathrm{a}} \pm 2,17$ & $141,39^{\mathrm{e}} \pm 15,80$ \\
\hline $\mathrm{CCl}_{4}$, silymarin $16 \mathrm{mg} / \mathrm{kg}$ & $113,60^{\mathrm{b}} \pm 26,80$ & $257,60^{\mathrm{b}} \pm 134,50$ & $1,93^{\mathrm{d}} \pm 0,20$ & $928,80^{\mathrm{b}} \pm 38,00$ \\
\hline $\mathrm{CCl}_{4}$ lá Trang to $100 \mathrm{mg} / \mathrm{kg}$ & $104,80^{\mathrm{b}} \pm 14,84$ & $137,40^{\mathrm{b}} \pm 26,30$ & $8,23^{\mathrm{b}} \pm 0,82$ & $520^{\mathrm{d}} \pm 49,30$ \\
\hline $\mathrm{CCl}_{4}$ lá Trang to $200 \mathrm{mg} / \mathrm{kg}$ & $84,20^{\mathrm{b}} \pm 20,02$ & $119,20^{\mathrm{b}} \pm 6,40$ & $4,47^{\mathrm{c}} \pm 0,36$ & $776,10^{\mathrm{c}} \pm 90,00$ \\
\hline $\mathrm{CCl}_{4, \text { lá Trang to } 400 \mathrm{mg} / \mathrm{kg}} 4^{\mathrm{b}} \pm 21,06$ & $88,80^{\mathrm{b}} \pm 14,62$ & $1,71^{\mathrm{d}} \pm 0,49$ & $1226^{\mathrm{a}} \pm 52,50$ \\
\hline
\end{tabular}

Ghi chú: Các giá trị có mẫu tự theo sau trong cùng một cột giống nhau thì khác biệt không có ý nghĩa thống kê ở mức 5\% $(p<0,05)$.

Hình thái gan của các công thức chuột sau thí nghiệm

Hình thái gan của các công thức chuột sau 4 tuần thí nghiệm được thể hiện trong hình 2 . Gan chuột uống nước cất (hình $2 \mathrm{~A}$ ) và gan chuột uống DMSO 1\% (hình 2B) có bề mặt trơn láng, mềm, mịn và có màu đỏ sậm. Trong khi đó, chuột uống $\mathrm{CCl}_{4}$ (hình $2 \mathrm{C}$ ) gan đã bị tổn thương, kích thước lớn do tế bào gan phình to, bề mặt gan gồ ghề, xơ dai. Các vùng trên gan có màu sắc không đồng nhất, phần lớn bị tái nhạt và đôi khi trên bề mặt xuất hiện các đốm màu bất thường. Riêng công thức chuột cho uống $\mathrm{CCl}_{4}$ và điều trị bằng silymarin (hình 2D) hoặc cao chiết lá I. duffii, gan chuột có nhiều cải thiện về mặt hình thái.
Bề mặt gan chuột điều trị bằng silymarin hơi gồ ghề so với chuột bình thường nhưng so với chuột gây bệnh bằng $\mathrm{CCl}_{4}$ thì mức độ tổn thương đã giảm rõ. Ở các công thức chuột gây bệnh bằng $\mathrm{CCl}_{4}$ được điều trị bằng cao lá, gan được cải thiện đáng kể so với chuột uống $\mathrm{CCl}_{4}$ không được điều trị. Gan của các công thức chuột gây bệnh được điều trị bằng cao chiết ở các nồng độ $100 \mathrm{mg} / \mathrm{kg}, 200 \mathrm{mg} / \mathrm{kg}$ và $400 \mathrm{mg} / \mathrm{kg}$ so với chuột bình thường khác biệt không nhiều. Màu sắc gan chuột ở nồng độ $100 \mathrm{mg} / \mathrm{kg}$ (hình 2E) tuy nhạt màu hơn bình thường, nhưng bề mặt gan đã giảm sự ghồ ghề và ở nồng độ $200 \mathrm{mg} / \mathrm{kg}$ (hình $2 \mathrm{~F}$ ) và $400 \mathrm{mg} / \mathrm{kg}$ (hình $2 \mathrm{G}$ ) thì màu sắc gan kể cả độ láng và các đặc điểm hình thái rất giống với chuột bình thường. 


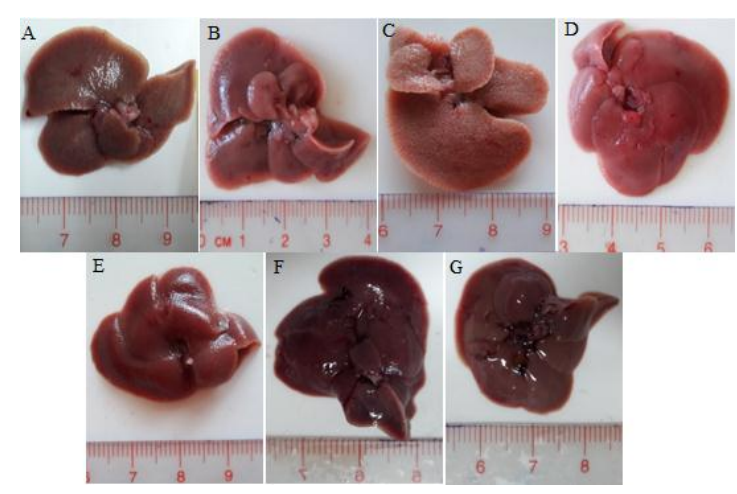

Hình 2. Hình thái bên ngoài của gan chuột thí nghiệm: (A) Chuột đối chứng sinh lý (uống nước cất); (B) Chuột uống DMSO 1\%; (C) Chuột đối chứng bệnh (uống $\mathrm{CCl}_{4}$ ); (D) Chuột bệnh uống silymarin; (E) Chuột bệnh uống cao chiết lá Trang to $100 \mathrm{mg} / \mathrm{kg}$; (F) Chuột bệnh uống cao chiêt lá $I$. duffii $200 \mathrm{mg} / \mathrm{kg}$; (G) Chuột bệnh uống cao chiết lá Trang to $400 \mathrm{mg} / \mathrm{kg}$

\section{Kết quả phân tích mô bệnh học}

Phân tích mô bệnh học gan của nhóm chuột đối chứng sinh lý cho thấy, cấu trúc gan bình thường với các tế bào gan tròn đều xếp khít nhau tạo thành các dãy hướng tĩnh mạch, nhìn rõ được xoang gan (hình $3 \mathrm{~A}$ ). Trong khi gan nhóm chuột đối chứng bệnh có cấu trúc bất thường (hình $3 \mathrm{~B}$ ), có nhiều tế bào bị hoại tử và tế bào mất nhân. Bên cạnh, có các tế bào gan tích trữ nhiều giọt lipid trở nên trương phồng và nhiễm mỡ hoặc màng của hai tế bào liên kề bị dính lại với nhau dẫn đến không xác định được xoang gan. Ngoài ra, có nhiều tế bào viểm quanh tiểu thùy, quanh mạch và len lõi giữa các tế bào. Ở nhóm được điều trị bằng silymarin hoặc cao chiết lá $I$. duffii có sự phục hồi đáng kể kiến trúc tế bào gan so với nhóm chuột đối chứng bệnh. Nhóm chuột gây bệnh được điều trị bằng silymarin (hình $3 \mathrm{C}$ ) có các tế bào gan có nhân tròn, đều xếp thành dãy hướng tĩnh mạch, quan sát được xoang gan. Các tê bào viêm giảm rõ rệt, tập trung chủ yếu quanh các cấu trúc mạch, kêt quả tương đương với nhóm chuột uống nước cất. Ở các nhóm chuột gây bệnh điều trị bằng cao chiết lá Trang to nồng độ 100, 200 hoặc $400 \mathrm{mg} / \mathrm{kg}$ trọng lượng chuột, trong mô gan các tế bào hoại tử, sự tích trữ lipid trong tế bào và tế bào viêm giảm dần (hình $3 \mathrm{D}-3 \mathrm{~F}$ ).

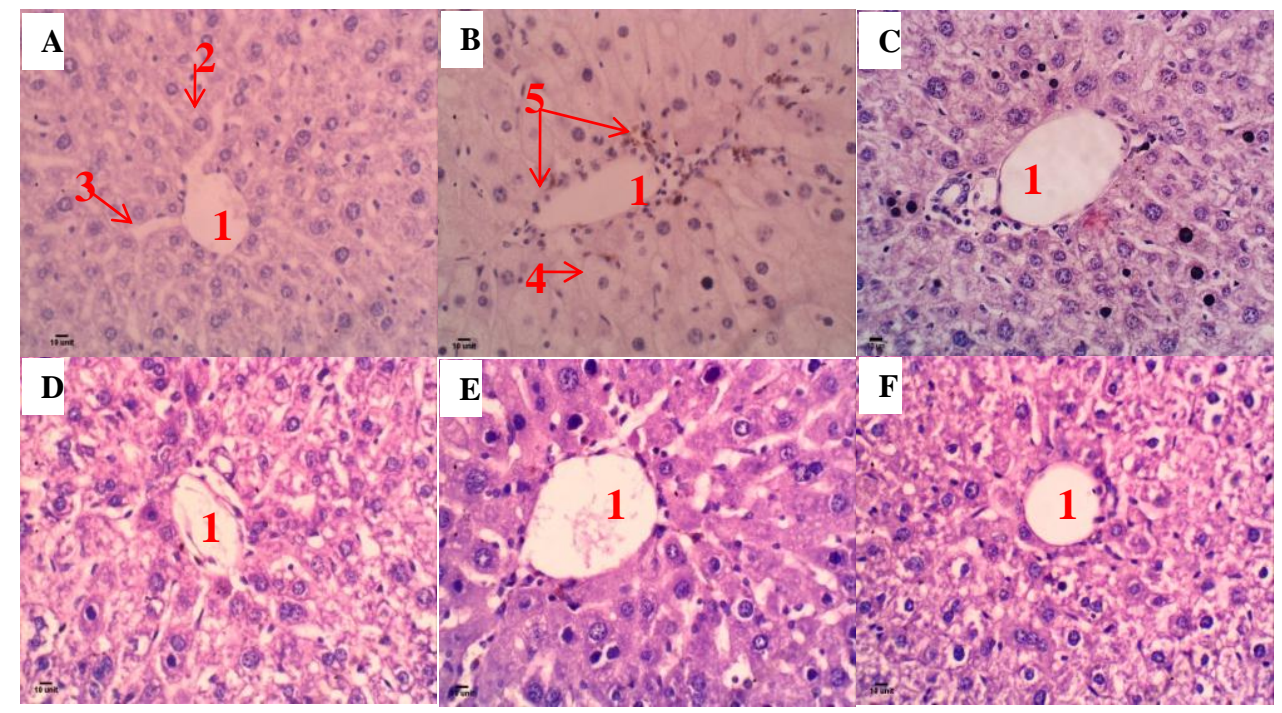

Hình 3. Vi phẫu gan ở các công thức chuột thí nghiệm nhuộm Hematoxylin và Eosin được quan sát dưới kính hiển vi độ phóng đại 400 lần: 1- Tĩnh mạch; 2- Tế bào gan bình thường; 3- Xoang gan; 4- Tế bào gan phồng to; 5- Tế bào viêm; (A) Chuột đối chứng sinh lý (uống nước cất); (B) Chuột đối chứng bệnh (uống $\mathrm{CCl}_{4}$ ); (C) Chuột bệnh uống silymarin; (D) Chuột bệnh uống cao chiết lá Trang to $100 \mathrm{mg} / \mathrm{kg}$; (E) Chuột bệnh uống cao chiết lá Trang to $200 \mathrm{mg} / \mathrm{kg}$; (F) Chuột bệnh uống cao chiết lá Trang to $400 \mathrm{mg} / \mathrm{kg}$ 


\section{THẢO LUẬN}

Khả năng chống oxy hoá của lá $I$. duffii được khảo sát dựa trên việc khử $\mathrm{Mo}(\mathrm{VI})$ thành Mo (V) bởi chất chống oxy hóa có trong cao chiết và hình thành phức phosphate/Mo $(\mathrm{V})$ có màu xanh ở $\mathrm{pH}$ acid (Prieto et al., 1999). Kết quả ở bảng 1 cho thấy rằng khả năng chống oxy hóa của cao chiết lá Trang to khá cao với hàm lượng chất chống oxy hóa ở nồng độ $100 \mu \mathrm{gg} / \mathrm{mL}$ cao chiết tương đương $12,02 \pm 0,18 \mu \mathrm{g} / \mathrm{mL}$ trolox. Hiệu quả chống oxy hóa của cao chiết lá I. duffii được so sánh qua giá trị $\mathrm{OD}_{0,5}$ thấp hơn trolox 6,7 lần. Hoạt tính chống viêm của lá Trang to được khảo sát thông qua khả năng ức chế sự biến tính protein. Sự biến tính protein mô là nguyên nhân chính dẫn đến các bệnh viêm do protein bị mất đi cấu trúc thứ cấp và cấu trúc bậc ba bởi stress bên ngoài hoặc các hợp chất như acid hoặc bazơ mạnh, muối vô cơ, dung môi hữu cơ hoặc nhiệt độ cao. Hầu hết protein sinh học khi bị biến tính sẽ bị mất đi hoạt tính sinh học (Shah et al., 2017). Do đó, đánh giá hoạt động ức chế sự biến tính protein là một phương pháp khảo sát khả năng chống viêm. Các sản phẩm hoặc hợp chất có khả năng ức chế sự biến tính protein được xem là tác nhân chống viêm hiệu quả (Mounnissamy et al., 2007).

Khả năng ức chế sự biến tính protein albumin huyêt thanh bò (BSA) của cao chiết lá $I$. duffii đã được chứng minh bởi sự so sánh với hoạt động tương tự của thuốc chống viêm diclofenac, kết quả cho thấy hiệu quả ức chế sự biến tính protein của lá $I$. duffii $\left(\mathrm{EC}_{50}=5,57\right.$ $\pm 0,12 \mu \mathrm{g} / \mathrm{mL})$ thấp hơn diclofenac $\left(\mathrm{EC}_{50}=\right.$ $0,57 \pm 0,21 \mu \mathrm{g} / \mathrm{mL}$ ) là 9,77 lần. Các cao chiết thực vật thường chứa nhiều chất chống $\mathrm{oxy}$ hóa và các hợp chất có khả năng làm sạch gốc tự do. Đồng thời các hợp chẩt phenolic và flavonoid ở thực vật đã được chứng minh có liên quan với các hoạt động chống sự biến tính protein (Imam et al., 2017), chống oxy hóa và chống viêm (Diaz et al., 2012). Kết quả nghiên cứu của chúng tôi cho thấy, trong lá $I$. duffii có sự hiện diện của các thành phần hóa học có hoạt tính sinh học như: alkaloid, flavonoid, anthraquinone, terpenoid, quinone, glycoside, coumarin và phenol. Đặc biệt lá $I$. duffii có thành phần polyphenol và flavonoid tổng khá cao (kết quả không hiển thị ở đây).
Chính vì vậy, cao chiết lá có hoạt tính chống oxy hóa và chống viêm khá tốt như trên.

Mặc khác, các quá trình viêm được kích hoạt bởi các tác nhân gây độc có liên quan mật thiết đến quá trình gây độc gan do hóa chất (Luster et al., 2000). Các quá trình viêm thường sản xuất ra các chất trung gian liên quan đến sự phát sinh các gốc tự do ảnh hưởng đến sự tổn thương gan hoặc sửa chữa mô gan. Do đó, cũng có thể thây rằng cao chiết có hoạt tính chống viêm cũng có thể biểu hiện hoạt tính bảo vệ gan (Joshy et al,, 2016). Carbon tetrachloride $\left(\mathrm{CCl}_{4}\right)$ được biết là tác nhân gây độc gan và đặc trưng của sự nhiễm độc gan do $\mathrm{CCl}_{4}$ là gan nhiễm mỡ, xơ gan và hoại tử (Huo et al., 2011).

Sự biến đổi sinh học $\mathrm{CCl}_{4} \sinh$ ra các gốc tự do phản ứng cao. Các gốc tự do có thể góp phần vào sự khởi phát và làm tiến triển xơ hóa trong gan (Poli, 2000). Do đó, mô hình gây nhiễm độc gan bằng $\mathrm{CCl}_{4}$ được sử dụng như mô hình thử nghiệm gây, tổn thương gan để sàng lọc các loại cao chiết hoặc thuốc bảo vệ gan (Refaey et al., 2015). Cho chuột uống $\mathrm{CCl}_{4}\left(2,5 \mathrm{ml} / \mathrm{kg}, 20 \% \mathrm{CCl}_{4}\right.$ trong dầu olive $)$ không gây chết và không ảnh hưởng đến hành vi chung và khối lượng cơ thể. Giai đoạn đầu uống $\mathrm{CCl}_{4}$, chuột bị lừ đừ ít hoạt động và ăn ít, nhưng sau một tuần chuột hoạt động bình thường sau mỗi lần uống và vần tăng khối lượng. Hơn nữa, sự gia tăng khối lượng cơ thể chuột cũng do sự gia tăng khối lượng gan do sự xâm nhập của các acid béo và glycerol vào tế bào gan qua màng tế bào bị tổn thương gây ra sự trương phồng tế bào và hoại tử tế bào gan dẫn đến sự thay đổi hình thái gan (hình $2 \mathrm{C})$ và thể hiện trên tiêu bản mô bệnh học của gan (hình $3 \mathrm{~B}$ ). Những thay đổi này đã được nhiều tác giả báo cáo do tác hại của $\mathrm{CCl}_{4}$ (Huang et al., 2012; Das et al., 2014; Simeonova et al., 2014).

Nồng độ các enzyme transaminase trong huyết thanh là dấu hiệu quan trọng để xác định mức độ nghiêm trọng của sự tổn thương gan. Chuột được gây bệnh với $\mathrm{CCl}_{4}$ làm tăng đáng kể hàm lượng enzyme ALT và $\mathrm{AST}$ trong huyết thanh cho thấy gan đã tổn thương (Kandimalla et al., 2016). Kết quả ở bảng 2 cho thấy, ở công thức đối chứng bệnh hàm 
lượng enzyme gan AST $(1386,40 \pm 354,50$ U/L) và $\operatorname{ALT}(921,20 \pm 375$ U/L) cao khác biệt có ý nghĩa thống kê so với công thức chuột đối chứng sinh lý. Chuột uống $\mathrm{CCl}_{4}$ kéo dài 4 tuần thì hàm lượng enzyme ALT tăng 26 lần so với chuột bình thường, chứng tỏ chuột uống $\mathrm{CCl}_{4}$ đã bị tổn thương gan. Hàm lượng enzyme ALT và AST trong huyết thanh cao ở chuột tổn thương gan giảm có ý nghĩa thống kê khi điều trị với silymarin hoặc cao chiết lá (bảng 2). Kết quả ở bảng 2 cho thấy, công thức chuột bệnh được điều trị bằng silymarin có hàm lượng AST và ALT lần lượt đo được trong máu là $257,60 \pm 134,00 \mathrm{U} / \mathrm{L}$ và $113,60 \pm 26,8$ U/L, vẫn còn cao hơn đối chứng sinh lý nhưng so với chuột đối chứng bệnh thì silymarin liều $16 \mathrm{mg} / \mathrm{kg}$ có hiệu suất làm giảm enzyme AST đạt $92,72 \pm 11,05 \%$ và ALT là $91,07 \pm 3,02 \%$. Từ đó, có thể thấy liều silymarin $16 \mathrm{mg} / \mathrm{kg}$ đã ức chế được tác hại $\mathrm{CCl}_{4}$, bảo vệ được gan chuột thí nghiệm.

Những nghiên cứu trước đây cho thấy silymarin có khả năng bảo vệ gan khỏi tổn thương do $\mathrm{CCl}_{4}$ gây ra (Refaey et al., 2015; Duong et al., 2016). Silymarin có hoạt tính chống oxy hóa, chống viêm và proapoptotic có thể ngăn chặn sự khởi đầu và tiển triển của các cơ chế gây tồn thương phát triển viêm gan thành xơ gan và ung thư gan (Federico et al., 2017). Cao chiết lá $I$. duffii có hoạt tính chống oxy hóa và chống viêm nên có khả năng bảo vệ gan. Các công thức chuột bệnh được điều trị bằng cao methanol lá Trang to ở các nồng độ 100, 200 hoặc 400 mg/kg có mức enzyme AST và ALT trong huyết thanh được cải thiện rõ rệt so với đối chứng bệnh. Ngay ở nồng độ 100 $\mathrm{mg} / \mathrm{kg}$ cao methanol lá Trang to đã làm giảm đáng kể hàm lượng enzyme AST (137,40 \pm $26,30 \mathrm{U} / \mathrm{L})$ và $\mathrm{ALT}(104,80 \pm 14,84 \mathrm{U} / \mathrm{L})$ huyết thanh, tương đương với hiệu quả của silymarin liều $16 \mathrm{mg} / \mathrm{kg}$ và khác biệt rất có ý nghĩa thống kê so với đối chứng bệnh. Ở nồng độ cao chiêt $400 \mathrm{mg} / \mathrm{kg}$, hàm lượng AST và ALT lần lượt là $88,80 \pm 14,62 \mathrm{U} / \mathrm{L}$ và $45,00 \pm 21,06 \mathrm{U} / \mathrm{L}$, tương đương với đối chứng sinh lý. Như vậy, cao chiê̂t lá $I$. duffii biểu hiện khả năng làm giảm AST và ALT huyết thanh rất tốt.

Glutathione (L- $\gamma$-glutamyl-Lcysteinylglycine) là nhóm thiol nội bào phổ biến nhất, với nồng độ nội bào từ khoảng 500 đến 10.000 nmol. Ở dạng khử, GSH là một chất chống oxy hoá đóng vai trò quan trọng trong bảo vệ tế bào khỏi tác hại của gốc tự do, làm giảm chất oxy hóa nội sinh và chống stress oxy hoá ngoại sinh (Yuan \& Kaplowitz, 2009; Enns \& Cowan, 2017) . Gây tổn thương gan bằng $\mathrm{CCl}_{4}$ làm giảm $\mathrm{GSH}$ trong gan và các chất bảo vệ gan hiệu quả sẽ làm phục hồi hàm lượng GSH trong mô gan (Lu et al., 2017). Qua kết quả nghiên cứu ở bảng 2 , hàm lượng GSH của công thức chuột đối chứng bệnh $(141,39 \pm 15,80 \mathrm{nmol} / \mathrm{g})$ thấp hơn chuột đối chứng sinh lý $(524,10 \pm 77,30 \mathrm{nmol} / \mathrm{g})$ là 3,71 lần. Ở công thức chuột gây bệnh được điều trị bằng silymarin đã phục hồi đáng kể mức GSH trong gan $(928,80 \pm 38 \mathrm{nmol} / \mathrm{g})$. Các công thức chuột gây bệnh được điều trị bằng cao chiết lá $I$. duffii có hàm lượng GSH tăng từ $520 \pm 49,30 \mathrm{nmol} / \mathrm{g}$ ở nồng độ 100 $\mathrm{mg} / \mathrm{kg}$ lên $1226 \pm 52,50 \mathrm{nmol} / \mathrm{g}$ ở nồng độ $400 \mathrm{mg} / \mathrm{kg}$. Như vậy, ở nồng độ $100 \mathrm{mg} / \mathrm{kg}$ cao chiết lá Trang to đã có thể điều hòa lượng GSH tương đương với hàm lượng GSH của chuột đối chứng sinh lý. Điều trị bằng cao chiết lá $I$. duffii ở nồng độ $400 \mathrm{mg} / \mathrm{kg}$ làm cho hàm lượng GSH tăng cao hơn chuột được cho uống silymarin liều $16 \mathrm{mg} / \mathrm{kg}$ là 1,32 lần.

Peroxide hóa lipid là một trong những đặc điểm chính của sự nhiễm độc gan gây ra do $\mathrm{CCl}_{4}$. MDA là sản phẩm peroxide hóa lipid, được hình thành bởi các gốc tự do tấn công màng tế bào và được sử dụng rộng rãi như là một dấu chuẩn sinh học về sự tổn thương peroxide hóa lipid (Simeonova et al., 2014). Tác nhân bảo vệ gan hiệu quả sẽ làm giảm được hàm lượng MDA trong mô gan (Tsai et al., 2017). Kết quả nghiên cứu ở bảng 2 cho thấy, công thức chuột đối chứng bệnh có hàm lượng MDA $(16,10 \pm 2,17 \mathrm{nmol} / \mathrm{g})$ cao gấp 8,26 lần và khác biệt có ý nghĩa thống kê so với chuột đối chứng sinh lý $(1,95 \pm 0,23$ $\mathrm{nmol} / \mathrm{g})$ hoặc chuột uống DMSO 1\% (2,01 \pm $0,20 \mathrm{nmol} / \mathrm{g}$ ). Sự gia tăng mức MDA ở gan cho thấy sự gia tăng peroxide hóa lipid, do đó dẫn đến tổn thương gan cũng như sự hoạt động kém hiệu quả của hệ thống bảo vệ chống oxy hóa. Tuy nhiên, mức MDA tăng được làm giảm sau khi điều trị bằng silymarin hoặc cao 
chiết lá. Hàm lượng MDA ở các công thức chuột tổn thương gan được điều trị bằng lá $I$. duffii giảm khác biệt có ý nghĩa thống kê khi tăng nồng độ cao chiết. Cao chiết lá Trang to ở nồng độ 100,200 và $400 \mathrm{mg} / \mathrm{kg}$ có hàm lượng MDA lần lượt giảm 1,$9 ; 3,6$ và 9,4 lần so với đối chứng bệnh. Cao chiết lá ở nồng độ $400 \mathrm{mg} / \mathrm{kg}$ cho hiệu quả giảm hàm lượng MDA trong gan chuột tương tự silymarin liều $16 \mathrm{mg} / \mathrm{kg}(1,93 \pm 0,20 \mathrm{nmol} / \mathrm{g})$.

Kết quả quan sát mô bệnh học cung cấp bằng chứng hỗ trợ cho phân tích sinh hóa. Silymarin là thuốc bảo vệ gan tiêu chuẩn được biết về khả năng bảo vệ màng tế bào và làm phục hồi sự tổn thương tế bào gan nhờ vào hiệu quả chống oxy hóa và chống viêm (Federico et al., 2017). Kết quả nghiên cứu cho thấy, cấu trúc mô gan của các công thức chuột bệnh điều trị bằng silymarin và cao methanol lá $I$. duffii được cải thiện rõ rệt (hình 3). Mô gan của công thức chuột bệnh điều trị bằng silymarin (hình $3 \mathrm{C}$ ) có các tế bào gan với nhân tròn đều xếp thành dãy tỏa ra từ tĩnh mạch trung tâm, nhìn rõ xoang gan và tế bào viềm đã giảm nhiều. Kết quả này tương tự với báo cáo của Duong et al. (2016). Đồng thời, hoạt động bảo vệ gan của các cao chiêt thực vật được biết có liên quan đến việc duy trì hệ thống bảo vệ chống oxy hóa trong gan cùng với hoạt động làm sạch các gốc tự do (Subba et al., 2017).

Các cơ chế bảo vệ bao gồm kích thích sự cảm ứng quá trình apoptosis trong các tế bào gan biến đổi, ức chế sự phát sinh hoặc loại bỏ ROS, làm giảm sự peroxide hóa lipid hoặc viêm trong gan và ngăn ngừa xảy ra hoại tử tế bào gan (Sanmugapriya \& Venkataraman , 2006). Cao chiết lá $I$. duffii có hoạt tính chống oxy hóa và chống viêm do có chứa thành phần polyphenol và flavonoid tổng khá cao. Nhờ vào hoạt tính chống oxy hóa và chống viêm, lá $I$. duffii có khả năng bảo vệ chống lại tổn thương gan do $\mathrm{CCl}_{4}$ gây ra. Ở công thức chuột bệnh điều trị bằng cao chiết lá ở nồng độ 100 $\mathrm{mg} / \mathrm{kg}$ khối lượng chuột, trong mô gan các tế bào hoại tử và sự tích trữ lipid trong tế bào đã giảm nhiều nhưng vẫn còn nhiều tể bào viêm quanh các tiểu thùy (hình $3 \mathrm{D}$ ), so với chuột đối chứng bệnh chưa khác biệt nhiều. Mô gan của công thức chuột bệnh được điều trị bằng cao chiết lá nồng độ $200 \mathrm{mg} / \mathrm{kg}$ có nhân tế bào tròn đều, giảm sự tích trữ các giọt lipid trong các tế bào, quan sát rõ các dãy gan tỏa ra từ tĩnh mạch trung tâm. Các tế bào viêm đã giảm xuống đáng kể (hình $3 \mathrm{E}$ ). Ở công thức chuột bệnh được điều trị bằng cao chiết lá nồng độ $400 \mathrm{mg} / \mathrm{kg}$ khối lượng chuột (hình $3 \mathrm{~F}$ ), mô gan được cải thiện gần giống với công thức chuột bệnh được điều trị bằng silymarin (hình $3 \mathrm{C})$ và chuột đối chứng sinh lý (hình $3 \mathrm{~A}$ ). Như vậy, ở các nồng độ khảo sát từ 100, 200 và $400 \mathrm{mg} / \mathrm{kg}$ cao chiết lá đều có tác dụng bảo vệ gan chống lại tổn thương do $\mathrm{CCl}_{4}$ gây ra theo hướng làm giảm tổn thương và phục hồi cấu trúc mô gan trở lại bình thường.

Từ các kết quả phân tích hóa sinh và mô bệnh học gan của các công thức chuột thí nghiệm cho thấy, ở nồng độ $400 \mathrm{mg} / \mathrm{kg}$ cao chiết lá $I$. duffii thể hiện hiệu quả bảo vệ gan tương tự thuốc tiêu chuẩn silymarin liều 16 $\mathrm{mg} / \mathrm{kg}$, chứng tỏ được tiềm năng của cao chiết lá trong bảo vệ gan.

\section{KẾT LUẬN}

Các số liệu trong nghiên cứu này đã chứng minh cao methanol lá $I$. duffii có khả năng chống oxy hóa, chống viêm và bảo vệ gan. Ở các nồng độ được khảo sát, cao methanol lá đều cho thấy khả năng làm giảm hàm lượng enzyme ALT, AST huyết thanh rất hiệu quả. Bên cạnh đó, cao lá còn cải thiện được trạng thái stress oxy hóa trong gan qua hiệu quả làm giảm lượng $\mathrm{MDA}$ và làm tăng lượng $\mathrm{GSH}$ trong mô gan. Việc sử dụng cao lá loài $I$. duffii cũng giúp cải thiện được cấu trúc mô học gan chuột thí nghiệm.

\section{TÀI LIẸU THAM KHẢO}

Aliyu A. B., Ibrahim M. A., Musa A. M., Musa A. O., Kiplimo J. J., Oyewale A. O., 2013. Free radical scavenging and total antioxidant capacity of root extracts of Anchomanes difformis Engl. (Araceae). Acta Poloniae Pharmaceutica-Drug Research, 70(1): 115-121.

Arauz J., Ramos-Tovar E., Muriel P., 2016. Redox state and methods to evaluate oxidative stress in liver damage: From 
bench to bedside. Annals of Hepatology, 15(2): 160-173.

Banu S., Bhaskar B., Balasekar P., 2012. Hepatoprotective and antioxidant activity of Leucas aspera against d-galactosamine induced liver damage in rats. Pharm Biol., 50: 1592-1595.

Chatterjee R., Mitra A., 2015. An overview of effective therapies and recent advances in biomarkers for chronic liver diseases and associated liver cancer. Int. Immunopharmacol., 24: 335-345.

Das M., Boerma M., Goree J. R., Lavoie E. G., Fausther M., Gubrij I. B., Pangle A. K., Johnson L. G., Dranoff J. A., 2014. Pathological Changes in Pulmonary Circulation in Carbon Tetrachloride $\left(\mathrm{CCl}_{4}\right)$-Induced Cirrhotic Mice. PLOS ONE, 9(4): e96043.

Diaz P., Jeong S.C., Lee S., Khoo C., Koyyalamudi S.R., 2012. Antioxidant and anti-inflammatory activities of selected medicinal plants and fungi containing phenolic and flavonoid compounds. Chinese Medicine., 7: 26.

Dontha S., Kamurthy H., Mantripragada B., 2015. Phytochemical and pharmacological profile of Ixora: A review. IJPSR., 6(2): 567-584.

Duong T. P. L., Cao T. K. H., Nguyen T. H., Duong X. C., Phan, T. B. T., Ha, T. T., 2016. Hepatoprotective effect of silymarin on chronic hepatotoxicity in mice induced by carbon tetrachloride. Journal of Pharmacognosy and Phytochemistry, 5(5): 262-266.

Enns G. M., Cowan T. M., 2017. Review Glutathione as a Redox Biomarker in Mitochondrial Disease-Implications for Therapy. J. Clin. Med., 6, 50.

Federico A., Dallio M., Loguercio C., 2017. Silymarin/Silybin and Chronic Liver Disease: A Marriage of Many Years. Molecules, 22: 191.

Habib N. C., Serra-Barcellona C., Honoré S. M., Genta S. B., Sánchez S. S., 2015. Yacon roots (Smallanthus sonchifolius) improve oxidative stress in diabetic rats. Pharm Biol., 53: 1183-1193.

Huang Q., Zhang S., Zheng L., He M., Huang R., Lin X., 2012. Hepatoprotective effects of total saponins isolated from Taraphochlamys affinis against carbonate trachloride induced liver injury in rats. Food Chem. Toxicol., 50: 713-718,

Huo H.Z., Wang B., Liang Y. K., Bao Y. Y., $\mathrm{Gu}$ Y., 2011. Hepatoprotective and antioxidant effects of licorice extract against $\mathrm{CCl}_{4}$-induced oxidative damage in rats. International Journal of Molecular Sciences, 12(10): 6529-6543.

Imam, S., Shaheen, N., Tasleem, F., Azhar, I., Mahmood, Z. A., Karachi, K. P., 2017. Evaluation of anti-inflammatory and other biological activities of flavonoid based cream formulation for topical application using in vitro model. International Journal of Pharmaceutical Sciences and Research, 8(10): 4388-4395.

Joshy C., Thahimon P.A., Kumar R. A., Carla B., Sunil C., 2016. Hepatoprotective, antiinflammatory and antioxidant activities of Flacourtia montana J. Grah leaf extract in male Wistar rats. Bulletin of Faculty of Pharmacy, Cairo University, 54: 209-217.

Kandimalla R., Kalita S., Saikia B., Choudhury B., Singh Y. P., Kalita K., Dash S., Kotoky J., 2016. Antioxidant and Hepatoprotective Potentiality of Randia dumetorum Lam. Leaf and Bark via Inhibition of Oxidative Stress and Inflammatory Cytokines. Frontiers in Pharmacology, 7: 205.

Kang, H., Koppula S., 2014. Hepatoprotective effect of Houttuynia cordata Thunb extract against carbon tetrachlorideinduced hepatic damage in mice. Indian $J$ Pharm Sci., 76(4): 267-273.

Li S., Tan H. Y., Wang N., Zhang Z. J., Lao L., Wong C. W., Feng Y., 2015. The Role of Oxidative Stress and Antioxidants in Liver Diseases. International Journal of Molecular Sciences, 16(11): 26087-26124.

Lu Y., Chen J., Ren D., Yang X., Zhao Y., 2017. Hepatoprotective effects of 
phloretin against $\mathrm{CCl}_{4}$-induced liver injury in mice. Food and Agricultural Immunology, 28(2): 211-222.

Luster M.I., Simeonova P.P., Gallucci R.M., Matheson J.M., Yucesoy B., 2000. Immunotoxicology: role of inflammation in chemical-induced hepatotoxicity. Int $J$ Immunopharmacol., 22: 1143-1147.

Medina J., Moreno O., Drugs R., 2005. Pathophysiological basis for antioxidant therapy in chronic liver disease. Drugs, 65: 2445-2461.

Moron M., Depierre J.W., Mannervik B., 1979. Levels of glutathione, glutathione reductase and glutathione s-transferase activity in rat lung and liver. Biochimica et Biophysica Acta, 582: 67-78.

Mounnissamy V.M., Kavimani S., Balu V., Darlin Quine S., 2007. Evaluation of antiinflammatory and membrane stabilizing property of ethanol extract of Cansjera rheedii J. Gmelin (Opiliaceae). Iran. J. Pharmacol. Ther., 6(2): 235-237.

Ohkawa H., Ohishi N., Yagi K., 1979. Assay for lipid peroxidation in animal tissues by thiobarbituric acid reaction. Anal Biochem., 95:351-358.

Phạm Hoàng Hộ, 2003. Cây Cỏ Việt Nam (Q. III). Nxb. Trẻ.

Poli G., 2000. Pathogenesis of liver fibrosis: Role of oxidative stress. Mol. Aspects Med., 21: 49-98.

Prieto P., Pineda M., Aguilar M., 1999. Spectrophotometric Quantitation of Antioxidant Capacity through the Formation of a Phosphomolybdenum Complex: Specific Application to the Determination of Vitamin E. Analytical Biochemistry, 269: 337-341.

Refaey M. S., Mustafa M. A. H., Mohamed A. M., Ali A. A., 2015. Hepatoprotective and antioxidant activity of Odontonema Cuspidatum (Nees) Kuntze against $\mathrm{CCl}_{4^{-}}$ Induced Hepatic Injury in Rats. Journal of
Pharmacognosy and Phytochemistry, 4(2): 89-96.

Saalu L. C., Ogunlade B., Ajayi G. O., Oyewopo A. O., Akunna G. G., Ogunmodede O. S., 2012. The hepatoprotective potentials of Moringa oleifera leaf extract on alcohol-Induced hepatotoxicity in wistar rat. Am. $J$. Biotechnol. Mol. Sci., 2(1): 6-14.

Sanmugapriya E., Venkataraman S., 2006. Studies on hepatoprotective and antioxidant actions of Strychnos potatorum Linn. seeds on $\mathrm{CCl}_{4}$-induced acute hepatic injury in experimental rats. $J$ Ethnopharmacol., 105: 154-160.

Shah M., Parveen Z., Khan M. R., 2017. Evaluation of antioxidant, antiinflammatory, analgesic and antipyretic activities of the stem bark of Sapindus mukorossi. BMC Complementary and Alternative Medicine, 17: 526.

Simeonova R., Kondeva-Burdina M., Vitcheva V., Mitcheva M., 2014. Some In Vitro/In Vivo Chemically-Induced Experimental Models of Liver Oxidative Stress in Rats. BioMed Research International. Article ID 706302, 6 pages.

Subba A., Dutta B., Sahu R. K., Mandal P., 2017. Antioxidant, anti-inflammatory, and hepatoprotective activity of Fraxinus floribundabark and the influence of extraction process on their bioactivity. Journal of Pharmacy Research, 11(8): 983-990.

Tsai J. C., Chiu C. S., Chen Y. C., Lee M. S., Hao X. Y., Hsieh M. T., Kao C.P., Peng W. H., 2017. Hepatoprotective effect of Coreopsis tinctoria flowers against carbon tetrachloride-induced liver damage in mice. BMC Complementary and Alternative Medicine, 17: 139.

Yuan L., Kaplowitz N., 2009. Review Glutathione in liver diseases and hepatotoxicity. Molecular Aspects of Medicine, 30: 29-41. 